Review of

ECONOMICS

and

INSTITUTIONS
Review of Economics and Institutions

ISSN 2038-1379 DOI:10.5202/rei.v10i1.289

Vol. 10 - No. 1, Spring-Summer 2019 - Article 3

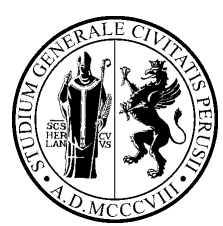

www.rei.unipg.it

\title{
The Euro's Effect on Trade: An Analysis of "Old" and "New" EMU Members
}

\author{
Isaac Mensah ${ }^{\bowtie}$ \\ $\mathrm{Ca}$ ' Foscari University \\ of Venice
}

\begin{abstract}
This paper provides new empirical evidence of the "euro effect" on bilateral trade by allowing for a heterogeneous impact on "new" and "old" EMU members. By applying a Pseudo-Poisson Maximum Likelihood (PPML) estimator and focusing on a sample of 38 countries, our results show a positive but statistically insignificant euro's effect on bilateral exports. However, disaggregating this effect, we report a relatively large euro's effect on bilateral trade for the "new" EMU countries. We also find no evidence of trade diversion, thus corroborating existing evidence. These results are robust to a number of sensitivity checks and, especially, to the use of a larger sample of countries. Finally, using country-pair and country-industry-pair data, our results indicate a reduction in export concentration in the bilateral trade of "old" EMU countries. Instead, we find an increase in concentration in trade between "new" and "old" EMU countries.
\end{abstract}

JEL classification: F4, F14, F15, F33, C33

Keywords: Gravity model; Bilateral exports; Euro; PPML estimator

Acknowledgments: I am grateful to Daniela Maggioni, Gennaro Zezza, Andrew Rose, Roberto Roson and the participants of the following international conferences: FIW, Austria (2017), CIE, Spain (2018), PEJ, Lisbon (2018) for their useful comments. The opinions expressed are those of the author.

$\bowtie$ Address: Ca' Foscari University of Venice, Department of Economics and Finance, San Giobbe, Cannaregio 873, 30121, Venice, Italy. Tel: +39 342 7414490. Mail:

sac.mensah@gmail.com

\section{Recommended Citation}

Mensah I. (2019). The Euro's effect on trade: An analysis of "old" and "new" EMU members. Review of Economics and Institutions, 10(1), Article 3. doi: 10.5202/rei.v10i1.289

Retrieved from http://www.rei.unipg.it/rei/article/view/286

Copyright (C) 2019 University of Perugia Electronic Press. All rights reserved 


\section{Introduction}

Since 2004, the European Union (henceforth, EU) has gained thirteen "new" member countries. " Some of these "new" members further deepened their integration in Europe by joining the European Monetary Union (henceforth, EMU). Slovenia joined the EMU in 2007, Malta and Cyprus in 2008, Slovakia in 2009, Estonia in 2011, Latvia in 2014 and Lithuania in 2015. ${ }^{2}$ The adoption of the euro allowed these "new" EMU member countries, which are small and open economies, to mitigate the risk of exchange rate fluctuations among themselves and in their trade relationships with other "old" EMU members. Moreover, the use of the euro reduced the severity of exchange rate fluctuations with non-EMU countries.

While the economic benefits of joining a monetary union could ensue in the early or later stage of the unification, the timing of membership to a monetary union can be crucial. Thus, a strong euro's effect in the early years of the introduction of the euro benefits the founding members. Since such an effect may not exist, exist but diminish or grow stronger over time, subsequent members are at a risk of joining a distress monetary union or an economically beneficial one. Recent findings on the subject seem to dispute the positive and statistical significance of the euro's effect on trade which was earlier found for the "old" EMU members. It is therefore important to distinguish the benefit of the euro into disaggregated effects according to the year of membership. We do so by categorizing EMU member countries into two groups. Of the nineteen EMU member countries, we identify Germany, France, Italy, Spain, Austria, Portugal, Greece, Belgium, Netherlands, Finland, Ireland and Luxembourg as "old" EMU countries while Cyprus, Estonia, Latvia, Lithuania, Malta, Slovakia and Slovenia are termed as "new" EMU countries.

A consensus among economists is yet to be reached on the euro's effect on trade. Indeed, existing evidence of the euro's effect on EMU members is mixed, by disclosing both positive, negative and insignificant effects of the euro adoption on trade. We aim at contributing to this strand of literature by providing new evidence on the topic, and in particular, by studying the role the euro may have played for the "new" EMU members' trade. For this reason, we include all the member countries of the EMU in our empirical analysis. We then test the existence of a heterogeneous euro's effect on trade according to the structural characteristics of "old" and "new" EMU members, looking at heterogeneity within the group of "old" members, within the group of "new" members and between old and new EMU members.

1 Bulgaria, Croatia, Cyprus, Czech Republic, Estonia, Hungary, Latvia, Lithuania, Malta, Poland, Romania, Slovakia and Slovenia.

2 Throughout the paper, we define as a "new" EMU member, any country from this list. 
In addition to estimating the disaggregated effect of the euro according to country groups, we extend the analysis to cover the impact of the euro's effect on bilateral export concentration of trade in the euro area. Since member countries of the euro area lose the option of using currency depreciation or devaluation as a competitive tool to improve bilateral trade within the eurozone, the ability of member countries to improve their trade balance rely heavily on non-price competitiveness such as R\&D expenditure, patent rights and investment in capital and human resources. This may induce some form of specialization in production leading to falling prices and plausible increases in the number and quality of tradable products within the euro area. Also, from a policy point of view, it is important to understand not just the aggregate or disaggregated effect of the euro but how the euro's effect on trade is improving consumer welfare with regards to falling prices and improvement in product quality and variety.

Focusing on the latter, we analyse the impact of the euro's effect on bilateral export concentration. We use 2-digit and 6-digit Harmonised System (HS) data to compute the Herfindahl-Hirschman Index (HHI) which represents our measure of export concentration. Our analysis of the euro's effect on bilateral trade and export concentration is based a theory-consistent empirical model following existing studies by Head and Mayer (2014), Rose (2017) and Larch et al., (2019). In our empirical analysis, we exploit the most recent (as at the time of writing) IMF-Direction of Trade (DOT) data spanning 1988 to 2015.

We report estimates using the Pseudo-Poisson Maximum Likelihood (henceforth, PPML estimator). As suggested by Santos Silva and Tenreyro (2006 henceforth, SST), the PPML estimator accommodates zero trade flows, and Larch et al., (2019) provides the algorithm for solving high-dimensional fixed effects using the PPML estimator. We control for both time-varying country-specific and time-invariant country-pair fixed effects, thus addressing both the multilateral resistance and endogeneity issues. We report results for the baseline model by focusing on a sample which includes both zero and non-zero trade flows.

After two decades since the introduction of the euro, we believe that there is room for renewed empirical studies. Also, the availability of more recent data and a longer post-euro time span could help in better identifying the euro's effect on trade. In this paper, we argue that empirical studies should pay attention to both the "old" and "new" EMU member countries and compare their experience. Despite the important role the EMU membership may have played for the "new" EMU countries, existing evidence on the euro's effect on trade is widely focused on the "old" EMU members and neglects the "new" EMU countries. Hence, our findings not only add to the scant literature of the euro's effect on the "new" EMU members but can be considered a good policy perspective for the EU countries ${ }^{3}$ in transit to the EMU.

3 Poland, Romania, Bulgaria, Croatia, Hungary and Czech Republic. 
To the best of our knowledge, the present paper is one of the few studies that disaggregate the euro's effect by identifying different effects associated to the trade flows involving "old" and "new" EMU member countries. The other existing recent works (Zymek et al., 2018; Larch et al., 2019; Ciéslik et al., 2014) do not include Latvia and Lithuania in the EMU estimates. Furthermore, differently, from Ciéslik et al. (2014), we use the PPML estimator in our empirical strategy. In addition, we enrich the analysis by shedding light on the impact of the euro adoption on the export concentration in the euro area, which is a novelty to the study of the euro's effect on trade.

Anticipating our results, we show a statistically non-significant euro's effect on trade. Our results are consistent with a number of recent studies (Larch et al., 2019; Mika and Zymek, 2018; Ciéslik et al., 2012, 2014) which focus on samples covering a large number of countries. However, disaggregating the effect, we report a relatively large euro's effect on trade of between 49-60 percent of bilateral exports for the "new" EMU member. Our results also indicate that the euro adoption has led to an increase in concentration of export in trade between "old" and "new" EMU countries. We, however, find a reduction in export concentration in trade among the "old" EMU members.

The rest of the paper is organized as follows. Section 2 reviews the existing literature, Section 3 offers a discussion of our methodology and data, Section 4 presents our results, Section 5 shows some sensitivity analysis and Section 6 concludes.

\section{Literature Review}

An understanding of how monetary variables, especially exchange rates, influence trade flows has long been studied by monetary and trade economists. The general consensus by economists on the ambiguous effect of exchange rates volatility on trade has driven researchers to focus on the study of currency unions and on their trade effects. Economists' thought of currency unions as having microeconomic benefits but macroeconomic costs (Rose, 2000) was only a theoretical possibility until the creation of the European Monetary Union. In the wake of the European monetary integration in 1999, Rose (2000) applied a gravity ${ }^{4}$ model in order to

4 Gravity as literately defined in the spirit of Newton's law is directly proportional to the mass of objects (say country $i$ and $j$ ) and inversely proportional to the distance

between them. Presented mathematically and in economic terms as; $G_{i j}=\frac{\text { GDPi GDPj }}{\text { Distij }}$.

The specification in Tinbergen (1962) is slightly different and given below as; $\left[G_{i j}=\alpha\right.$ $\operatorname{GDP}_{\mathrm{i}^{\mathrm{i}}}{ }^{1} \mathrm{GDP}_{\mathrm{j}^{\mathrm{a}}}{ }^{2}$ Dist $\left._{\mathrm{ij}}{ }^{3}\right]$. Thus, $\mathrm{G}$ is the bilateral trade flows, GDP represents the market size, Dist is the bilateral geographical distance between countries and $\alpha$ is constant parameters. 
answer a simple question "What is the currency union effect on international trade". In his cross-sectional study of 186 countries, characterized mainly by poor, small and open economies, Rose (2000) concluded that countries with a common currency trade three times as much than they would have otherwise. His findings, though interesting, were taken by researchers with a pinch of salt, leading to the revival of the currency union effect literature. Other panel studies (Glick and Rose, 2002; Rose and van Wincoop, 2001 among others) were further developments on the subject and a year after the publication of Rose (2000), a number of authors $^{5}$ identified some theoretical and empirical flaws in his work.

Baldwin (2006) raised three main critiques of the work by Rose (2000): omitted variables, reverse causality and model misspecification. It is worth mentioning that the identification of the currency union's effect in Rose (2000) rests on the exploitation of cross-country heterogeneity. Persson (2001) questioned the validity of Rose's country selection and proposed the use of a "matching strategy" for the sample selection.

By reviewing the euro's effect literature, Baldwin (2006) re-classified errors in the empirical estimation of the gravity model into gold, silver and bronze medal errors. These errors relate to the wrongful measurement of variables and specification of the gravity model. The gold medal error refers to the omission of relative prices the so-called multilateral resistance problem in the empirical estimation, while the silver medal error concerns the definition of the dependent variable which, preferably, should be represented by bilateral exports. The bronze medal error relates to the conversion of nominal variables into real variables which tends to over/underestimate the variables. That notwithstanding, there still exist contrasting empirical measurements and specifications of the gravity model even in recent contributions.

By building on the Rose (2000)'s contribution, Micco et al. (2003) were the first to study the euro's effect on trade. Moreover, their empirical model was an improvement ${ }^{6}$ on earlier contributions, given the updated empirical and theoretical developments in Persson (2001), Tenreyro (2001), Baldwin (2006) and Rose and Van Wincoop (2001). By studying 22 developed countries (including 15 European countries) for the period 1992 to 2002, they found that the euro's adoption led to an increase in bilateral trade by 8 to 16 percent. Furthermore, they also reported no evidence of trade diversion. Others, ${ }^{7}$ such as Barr et al. (2003), Flam and Norstrom (2003) and Berger and Nitsch (2008), using similar estimation methods have reported somewhat similar results.

Prior to their membership in the EMU, all the "new" EMU countries, considered in "euro effect" studies, were used as a control sample. However, some studies anticipated the EMU integration of some Central

5 See Persson (2001) and Tenreyro (2001).

6 For example, they avoided the gold medal mistake by including a measure of relative prices (exchange rates) in their empirical model.

7 See Rose (2017) which list a number of recent contributions. 
and Eastern European Countries (henceforth, CEECs), by considering countries such as Slovenia, Latvia, Estonia etc., as EMU countries prior to their membership. Maliszewska (2004) and Belke and Spies (2008) are a few known ex-ante analyses of the euro's effect on a selected group of "new" EMU countries.

By estimating both Ordinary Least Squares (OLS) and panel fixed effects (FE) models, Maliszewska (2004) reported a euro effect in the range of 6-26 percent on trade. She assumed that any CEEC joining the euro will have a similar trade effect. Based on this assumption, she made a forecast of the euro's effect for the CEECs yet to join the EMU. Her conclusion from the forecast was that less open economies like Latvia and Lithuania will have a significant increase in trade compared to economies like Estonia and Slovakia who were relatively more opened. Interestingly, the conclusion in Belke and Spies (2008) contrasts with the above findings. Thus, using a Hausman-Taylor approach on a sample of CEECs and Organization of Economic Cooperation and Development (henceforth, OECD) countries for the period 1992-2004, they concluded that except for Poland, Latvia and Lithuania, all other CEECs that had joined the EMU would have experienced an increase in trade.

The need for expanding empirical investigations on the "euro effect" by including the analysis of the "new" EMU members became even more apparent after Slovenia and other CEECs joined the EMU beginning in 2007. Cieślik et al. (2014) is one of the few ex-post euro studies of the "euro effect" on the "new" EMU members. In their study, they use a data set similar to that in Rose (2000) for the period 1990-2010. Using a panel (FE) estimator, they concluded that the elimination of exchange rate volatility by joining the Exchange Rate Mechanism (ERM II) resulted in trade expansion for the "new" EMU members. However, their EMU accession did not have any positive effect on trade.

The conclusion above is consistent with their earlier studies (Cieślik et al., 2012) which considered only Slovenia and Slovakia as the "new" EMU countries. More recently, Mika and Zymek (2018) by adopting both OLS and PPML estimators on a sample of EU and 7 developed countries for the period 1992-2002, found no evidence of a positive euro effect on trade for the "old" EMU countries. The same evidence is corroborated when they expand the sample to include 153 countries for the period 1992-2013. Finally, they found no significant effect for the "new" EMU members either.

Our work differs from existing ones in the following: (i) the estimator used (ii) includes all EMU and EU member countries and (iii) focus on export concentration in the euro area. More importantly, this work is related to studies by Mika and Zymek (2018) and Larch et al., (2019) in terms of the estimation methodology used. However, we consider a larger sample of "new" EMU members, investigating a longer post-euro time span in our estimation. In addition, and different from Zymek et al. (2018), we estimate a euro's effect on bilateral exports among the "old" EMU countries, among the "new" EMU countries and between the "old" and "new" EMU countries. 
The findings of this work add to the recent policy debate about trade in the euro area and the benefits of adopting the euro by countries in transition. In the light of increasing globalization and world trade, intra-euro area trade flows have risen significantly above their average in the 1990s. As shown in Figure A1.1 (see appendix), euro area trade peaked in 2008 at about 4,672 billion US dollars. Since then trade in the euro area has fluctuated in the last decade partly because of the global financial crisis in 2007-2008 and the European debt crisis. Thus, the value of the intra-euro area trade is yet to reach its peak in 2008. Interestingly, since 2002 the gap between intra and extra-euro area trade seems to have widened, which implies the continuous growth in trade between EMU and non-EMU members despite the euro initiative.

Moreover, focusing on the "new" EMU members' trade in the euro area, Figure A1.2 (see appendix) shows an upward trend in the share of intra-euro trade by the "new" EMU members except for Slovenia. As at 2017, Lithuania's share of intra-euro trade rose from 1.5 to 4.5 percent, while that of Slovenia remained fairly constant between 0.5 to 0.9 percent. Moreover, Slovakia's share stood at 0.9 to 2.3 percent, Estonia at 1 to 3.3 percent, Cyprus 1.1 to 3.4 percent, Latvia 1.1 to 3.8 percent and Malta 1.3 to 3.9 percent. Clearly, the adoption of the euro by these "new" EMU members has played a significant role in their trade in the euro area.

\section{Empirical Methodology and Data}

Bergstrand (1990) formulated a demand-side model that deviated from the conventional homogeneous endowments (factors) assumption, thus accounting for the differences in factor endowment. The resulting empirical suggestion is to include Gross Domestic Product (GDP) per capita in the gravity model specification. Furthermore, Anderson and Van Wincoop (2001), an update on Anderson (1979), introduced the concept of multilateral resistance term and suggested the need to relax the homogeneous price assumption due to border effect. This led to the inclusion of relative price variables in the gravity model specification. In order to account for this effect, researchers include time-varying importer and exporter fixed effects in the gravity specification.

Our baseline analysis mainly rests on a sample of OECD countries. This is an attempt to focus on a fairly homogeneous group of countries. That notwithstanding, we recognize that OECD countries are differentiated in several factors. Moreover, we also acknowledge the differences between the "old" and "new" EMU countries. To date, there still exist some differences in the institutional setup and economic structure among member states which lead to the lags in the implementation of euro-wide policies among member states.

The literature shows that the choice of the sample of countries under analysis matters for the identification of the euro's effect on trade. In particular, Rose (2017) argues in favour of using larger samples. However, the inclusion of many smaller countries tends to exacerbate the difference in estimated effects between estimators. For example, OLS estimator tends 
to put relatively more weight on smaller trade flows compared with PPML (Larch et al., 2019). Hence, while we decided to focus on a smaller sample $^{8}$ of OECD countries, we also show the robustness of our findings by extending the sample to include a larger set of countries. More interesting, by exploiting our baseline sample, we arrive at a conclusion similar to those in Larch et al., (2019) and Mika and Zymek (2018) who used a relatively large sample.

After the publication of Santos Silva and Tenreyro (2006), the Pseudo-Poisson Maximum Likelihood (PPML) estimator has been embraced in the gravity model literature. Indeed, it is consistent in the presence of heteroskedasticity, and it offers a natural treatment for missing bilateral trade flows for which alternative treatments in the literature are found to generate inconsistent estimates of parameters. Finally, with respect to other estimators (like Least Square Dummy Variable (LSDV)), the PPML report non-bias estimates (in terms of magnitude) of dyadic dummies. We avoid Baldwin's gold medal error by including exporter-year and importer-year fixed effects to control for multilateral resistance, silver medal error by using bilateral export trade as the dependent variable and bronze medal error by estimating our gravity model in nominal terms. Hence, our PPML gravity specification is the following:

$$
X_{i j t}=\exp \left\{\beta_{0}+\beta_{1} F T A_{i j t}+\beta_{2} E U_{i j t}+\beta_{3} E M U_{i j t}+\alpha_{i t}+\delta_{j t}+\phi_{i j}\right\}+\varepsilon_{i j t}
$$

The dependent variable is the bilateral exports between country $i$ and $j$ at time t. Free Trade Agreements (henceforth, FTA) is the trade policy dummy indicating whether both countries are/were members of some free trade agreements. EU and EMU are the institutional dummies indicating whether both countries are members of the European Union and the European Monetary Union respectively. It is important to emphasize that EMU is the dummy of interest which captures the euro's effect on trade. The EU dummy accounts for the various institutional changes in the EU disentangling these effects from the EMU effect.

EMU is further disaggregated into $E M U_{\text {old, }} E M U_{\text {new }}$ and $E M U_{\text {oldnew. }}$ $E M U_{\text {old }}$ takes the value 1 for the pair of "old" EMU countries and 0 otherwise, while EMU $U_{\text {new }}$ takes value 1 for the pair of "new" EMU countries and 0 otherwise, and $E M U_{\text {oldnew }}$ takes value 1 for the pair of "old" and "new" EMU countries and 0 otherwise. $\alpha$ it and ojt are the time-varying exporter and importer fixed effects respectively and $\phi i j$ captures country-pair fixed effects. Finally, $\varepsilon_{\mathrm{ijt}}$ is the error term.

We also report estimates of an alternative specification where we use countries' GDP and bilateral exchange rates (EX) as controls for multilateral resistance, instead of including exporter-year and importer-year fixed effects, but we include country-pair fixed effects as

8 See Figure 1 on page 21 of Rose (2017). The literature reflects significant number of small sample studies. 
controls for endogeneity. While we expect the EU dummy to be positive, EMU could be negative or positive reflecting the inconclusiveness of the euro's effect on trade in the literature. However, when disaggregating the total EMU effect, we expect a larger and positive euro's effect on the "new" EMU members. While the theoretical literature on trade suggests a positive FTA on trade, there exists a large empirical literature that concludes on the ambiguous effects of FTA on trade. Given this inconclusiveness, we are receptive to the outcome of the FTA dummy.

Moreover, regardless of a positive, negative or zero euro's effect on trade, we estimate trade diversion (DV) effect by means of the following specification:

$X_{i j t}=\exp \left\{\beta_{0}+\beta_{1} F T A_{i j t}+\beta_{2} E U_{i j t}+\beta_{3} E M U_{i j t}+\beta_{4} D V_{i j t}+\alpha_{i t}+\delta_{j t}+\phi_{i j}\right\}+\varepsilon_{i j t}$

In equation (2) all variables follow their definition given in equation (1). DV is a dummy which takes the value 1 for the pair of EMU and non-EMU countries and 0 otherwise. A positive coefficient of the DV dummy implies no evidence of trade diversion while a negative coefficient indicates otherwise. An analysis of trade diversion in the EMU was first done by Micco et al., (2003). In their work, they found no evidence of trade diversion. We expect similar results as trade (both pre and post-EMU integration) between EMU and non-EMU members have not changed significantly (both EU and non-EU alike), looking at the global pattern of trade. And more so, EU-China trade flows have grown steadily in recent years, showing the EU's sustained interest in external markets.

\subsection{Data}

Our study is focused on all member countries of the EU, OECD and some non-OECD member countries. The sample includes 38 countries which are: Austria, Belgium, Britain, Cyprus, Czech Republic, Denmark, Estonia, Finland, France, Germany, Greece, Italy, Ireland, Latvia, Hungary, Romania, Bulgaria, Croatia, Iceland, Poland, Luxembourg, Lithuania, Malta, Netherlands, Norway, Portugal, Spain, Slovakia Republic, Slovenia, Sweden, Switzerland, Australia, Canada, New Zealand, Japan, China, India, US. The estimates cover the period from 1988 to 2015 . Hence, our analysis is implemented on a balanced panel with a total of 39,368 observations (given by $38 \times 37 \times 28$ ).

Bilateral trade data are sourced from the International Monetary Fund's (IMF) Direction of Trade Statistics (DOTS), while data on GDP are from the World Bank's World Development Indicators (WDI). Bilateral exporter and importer exchange rates (period averages) data are from the OECD.stat database. For Bulgaria, Cyprus, Croatia, Malta and Romania, we used exchange rates data from the WDI. Finally, trade policy (free-trade agreement) data are from the Mario Larch's Regional Trade Agreements Database in Egger and Larch (2008).

Both EU and EMU dummies are created with particular reference to country's year of membership in the EU and EMU. In this work, countries who were members of the EMU by 2001 are classified as "old" EMU 
members, while those who gained membership subsequent to 2001 are deemed "new" EMU countries. Also, to account for their prominent role in recent international trade flows, China and India are included in our data.

\section{Empirical Results and Discussion}

\subsection{Bilateral Export in the Euro Area}

Table 1 presents the results of the estimation of equation (1) by adopting the PPML estimator. The models are estimated on the whole sample of 38 countries for the period 1988-2015. We report estimates using bilateral exports (dependent variable) that include both zero and non-zero trade flows. We estimate two baseline specifications. While in Model 1, we treat both "old" and "new" EMU groups as homogeneous, and we estimate a single effect for the whole set of EMU members, in Model 2 we split them between "old" and "new" EMU members and we estimate heterogeneous effects for three different groups of country pairs: "old-old" EMU members, "new-old" EMU members, "new-new" EMU members.

Our results are consistent with our expectations in terms of sign and magnitude. The trade benefits of joining the EMU is small, negative and statistically insignificant with reference to our baseline model [column 3]. When disaggregating the total "euro-effect" [column 4], our results indicate that the euro has been highly beneficial for trade flows taking place within the group of "new" EMU members. As indicated by the $E M U_{n e w}$ dummy, the reported "euro effect" is as high as 49 percent $^{9}$ compared to that of the "old" EMU countries (indicated by EMU old), which is negative and statistically insignificant. Interestingly, the "euro effect" on the trade between the "new" and "old" EMU countries (indicated by $\mathrm{EMU}_{\text {oldnew }}$ ), though positive, is statistically insignificant.

Our results from the alternative baseline model show a large, positive and statistically significant euro's effect on trade [column 1]. Furthermore, they also show a similar euro's effect on the "old" EMU countries. It is indeed evident that an inadequate specification of the multilateral resistance term in the structural gravity model can bias the estimates of the euro's effect. Thus, time-varying exporter and importer fixed effects are important to account for changes in multilateral resistance (Feenstra, 2004; Baldwin and Taglioni, 2007).

The larger "euro effect" on the "new" EMU countries needs further clarification. These countries, prior to their EU integration, were less open to the international market with respect to the "old" EMU members. Thus, their EU membership gave them unlimited access to the larger EU market, providing a possibility for these countries to have (i) stable institutions guaranteeing democracy, the rule of law, human rights and respect for

9 This value is computed by; [(exp-1) $\times 100]$, where $\beta$ is the estimated coefficient of the $\mathrm{EMU}_{\text {new }}$ dummy. 
and protections of minorities (ii) a functioning market economy and the capacity to cope with competition and market forces in the EU and (iii) the ability to take on and implement effectively the obligations of membership, including adherence to the aims of political, economic and monetary union. Moreover, their further integration in Europe by joining the EMU gave them further trade advantages in terms of price transparency, mitigation of external price volatility and other frictions related to cross-border trade.

Table 1. PPML- Baseline Estimates

\begin{tabular}{|c|c|c|c|c|}
\hline \multicolumn{5}{|c|}{ World (38) Sample-Baseline: Dependent Variable: Bilateral Exports } \\
\hline VARIABLES & Model [1] & Model [2] & Model [3] & Model \\
\hline \multirow[t]{2}{*}{ InGDPeGDPm } & $0.744^{* * *}$ & $0.748 * * *$ & & \\
\hline & $(0.077)$ & $(0.076)$ & & \\
\hline \multirow[t]{2}{*}{ InEXe } & $0.384^{*}$ & $0.381 *$ & & \\
\hline & $(0.202)$ & $(0.201)$ & & \\
\hline \multirow[t]{2}{*}{ InEXm } & -0.077 & -0.078 & & \\
\hline & $(0.129)$ & $(0.129)$ & & \\
\hline \multirow[t]{2}{*}{ FTA } & 0.014 & -0.001 & 0.065 & 0.069 \\
\hline & $(0.093)$ & $(0.090)$ & $(0.051)$ & $(0.051)$ \\
\hline \multirow[t]{2}{*}{ EU } & 0.218 & 0.232 & $0.137 * *$ & $0.123 * *$ \\
\hline & $(0.170)$ & $(0.168)$ & $(0.061)$ & $(0.059)$ \\
\hline \multirow[t]{2}{*}{ EMU } & $0.415^{* * *}$ & & -0.031 & \\
\hline & $(0.105)$ & & $(0.060)$ & \\
\hline \multirow[t]{2}{*}{$E M U_{\text {old }}$} & & $0.459 * * *$ & & -0.062 \\
\hline & & $(0.115)$ & & $(0.067)$ \\
\hline \multirow[t]{2}{*}{$E M U_{\text {new }}$} & & $0.353 * * *$ & & $0.397 * *$ \\
\hline & & $(0.118)$ & & $(0.156)$ \\
\hline \multirow[t]{2}{*}{ EMU oldnew } & & -0.012 & & 0.114 \\
\hline & & $(0.233)$ & & $(0.072)$ \\
\hline Exporter Year FE & NO & NO & YES & YES \\
\hline Importer Year FE & NO & NO & YES & YES \\
\hline Country-pair FE & YES & YES & YES & YES \\
\hline Year FE & YES & YES & NO & NO \\
\hline Observations & 35,068 & 35,068 & 36,026 & 36,026 \\
\hline$R^{2}$ & & & 0.942 & 0.943 \\
\hline
\end{tabular}

***,**,* represent $1 \%, 5 \%$ and $10 \%$ significant level respectively, standard errors are in brackets. The dependent variable (bilateral exports) include zero and non-zero trade flows.

Further analysis of our results as shown in Figure A.2 and Table A.2 (see appendix) indicate that the aggregate "euro effect" began to improve during the period of membership of some "new" EMU members. From its introduction in 1999 till 2008, the euro has had a negative effect on trade except for the large positive effect in 2002 when euro banknotes and coins were first used for commercial activities. The results seem to indicate that the effect of the group of "new" EMU members slowed the negative aggregate euro's effect which later turned to positive from 2009 till 2014. 
This evidence revealed by the data is at the core of our strategy to disaggregate the euro's effect focusing on countries groups.

Our results also suggest that the creation of the European single market (EU) had a positive and statistically significant effect on trade. A result consistent with the argument documented in Berger and Nitsch (2008). Importantly, EU membership comes with the removal of obstacles to the free movement of goods, capital and labour, in the spirit of transparent and falling prices through competition. The EMU provides members with all the EU benefits together with sharing a common currency and monetary policy with other members. Thus, one has to disentangle the two to avoid plausible overestimation of the EMU effect. We also find a positive but insignificant effect of free trade agreements on trade. In recent literature, Larch et al., (2019) and Zymek et al., (2018) have found a positive, significant but small FTA effect on trade.

\subsection{Export Concentration in the Euro Area}

Recent literature has shown a positive welfare impact of the adoption of the euro. This is evident by the fall in prices across the euro area through tougher competition associated with enhanced transparency and lower transaction costs (Fontagné et al., 2009) and the increase in extensive and intensive margins of trade (De Nardis et al., 2008; Baldwin et al., 2008; Berthou and Fontagné, 2008). Thus, the introduction of the euro may have increased the availability of differentiated varieties of both final and intermediate products. Moreover, the single currency may have helped new exporters to enter euro-area markets. It may also have helped existing exporters to increase the number of products exported and the number of destinations they export to (Fontagné et al., 2009).

An analysis at the aggregate level of exports mask heterogeneous effects across sectors and products. Stated differently, an evidence of a no significant trade effect (as shown in Table 1) of the euro adoption at country level may not necessarily imply a no shift in the number of tradable products and in the export share they account for. For example, a reduction in the average export of richer (expensive) product variety could be compensated for by an increase in the average export of existing and new less rich ones. Thus, it is plausible for countries to experience no significant change in their aggregate bilateral trade flows, but rather a dramatic change in the composition and concentration of their trade flows.

We use a similar estimation approach as done in equation (1) to estimate the euro impact on the extent of export concentration. We compute an index of bilateral export concentration (HerfindahlHirschman Index, $\mathrm{HHI}$ ) as:

$$
H H I_{i j t}=\sum_{p=1}^{N} S_{P i j t}^{2}
$$

where $S p_{i j t}$ is the share of the total trade of an export product $p$ from country $\mathrm{i}$ to country $\mathrm{j}$ at time $\mathrm{t}$. Thus, $\mathrm{HHI}_{\mathrm{ijt}}$ measures the level of export 
concentration in the bilateral export of countries $i$ and $j$ at time $t$. Using $\mathrm{HHI}_{\mathrm{ijt}}$ as the dependent variable, we re-estimate equation (1) given below as:

$$
H H I_{i j t}=\exp \left\{\beta_{0}+\beta_{1} F T A_{i j t}+\beta_{2} E U_{i j t}+\beta_{3} E M U_{i j t}+\alpha_{i t}+\delta_{j t}+\phi_{i j}\right\}+\varepsilon_{i j t}
$$

All variables in equation (4) follow their respective definition as given in the previous equations. Moreover, in equation (4) coefficient $\beta 3$ represents the estimate of the "euro effect" on export concentration. A negative coefficient shows a fall in export concentration while a positive coefficient indicates otherwise. In other words, a negative coefficient implies an increase in the number of tradable commodities or a more balanced distribution of exports across products/industries as a results of the euro introduction, while a positive coefficient indicates a fall in the number of traded goods or a more unbalanced distribution of exports across products / industries. We use Harmonized System (HS) 2-digit trade data $^{10}$ from UN COMTRADE database to compute the Herfindahl Index. Using this index, we estimate the euro's effect on export concentration both at country-pair and country-industry-pair levels.

Table 2 presents the estimates of export concentration in the euro area based on export flows at 2 digit HS level. Our preferred specification covers the period 1988 to 2015, however, we also report estimates for the period 1993 to 2015. This period definition is in reference to Baldwin (2006) which will be discussed extensively in the next section. From Table 2 , our aggregate results indicate no evidence of a significant impact of the euro's effect on bilateral export concentration (using HS 2-digit data). This is confirmed in both 1988-2015 and 1993-2015 sample periods. The EMU dummy though positive is statistically insignificant. Increased competition across the euro area may alter the production of commodities and the composition of exchanged products by member countries. The evidence of no significant change in the aggregate bilateral export concentration might be the result of the net changes in exchanged commodities produced by member countries.

All variables in equation (4) follow their respective definition as given in the previous equations. Moreover, in equation (4) coefficient $\beta 3$ represents the estimate of the "euro effect" on export concentration. A negative coefficient shows a fall in export concentration while a positive coefficient indicates otherwise. In other words, a negative coefficient implies an increase in the number of tradable commodities or a more balanced distribution of exports across products/industries as a results of

10 We use a further disaggregated (HS) 6-digit data from International trade database (BACI) for the period 1995 to 2011 to study the level of bilateral export concentration at industry-level. The results seem mixed at the industry-level; however, we see a significant fall in bilateral export concentration for some industries in the trade among the "old", "new" and between the "old" and "new" EMU countries. 
the euro introduction, while a positive coefficient indicates a fall in the number of traded goods or a more unbalanced distribution of exports across products / industries. We use Harmonized System (HS) 2-digit trade data from UN COMTRADE database to compute the Herfindahl Index. Using this index, we estimate the euro's effect on export concentration both at country-pair and country-industry-pair levels.

Table 2 presents the estimates of export concentration in the euro area based on export flows at 2digit HS level. Our preferred specification covers the period 1988 to 2015, however, we also report estimates for the period 1993 to 2015. This period definition is in reference to Baldwin (2006) which will be discussed extensively in the next section.

From Table 2, our aggregate results indicate no evidence of a significant impact of the euro's effect on bilateral export concentration (using HS 2-digit data). This is confirmed in both 1988-2015 and 1993-2015 sample periods. The EMU dummy though positive is statistically insignificant. Increased competition across the euro area may alter the production of commodities and the composition of exchanged products by member countries. The evidence of no significant change in the aggregate bilateral export concentration might be the result of the net changes in exchanged commodities produced by member countries.

Table 2. Estimates of Export Concentration in the Euro Area

\begin{tabular}{|c|c|c|c|c|}
\hline \multicolumn{5}{|c|}{ World (38) Sample Dependent Variable: HH Index } \\
\hline \multirow[b]{2}{*}{ VARIABLES } & \multicolumn{2}{|c|}{ 1988-2015 } & \multicolumn{2}{|c|}{ 1993-2015 } \\
\hline & Model [1] & Model [2] & Model [3] & Model [4] \\
\hline \multirow[t]{2}{*}{ FTA } & $-0.081 * * *$ & $-0.081 * * *$ & $-0.079 * * *$ & $-0.078 * * *$ \\
\hline & $(0.019)$ & $(0.019)$ & $(0.020)$ & $(0.020)$ \\
\hline \multirow[t]{2}{*}{ EU } & $-0.086 * * *$ & $-0.096 * * *$ & $-0.077 * * *$ & $-0.087 * * *$ \\
\hline & $(0.023)$ & $(0.023)$ & $(0.024)$ & $(0.025)$ \\
\hline \multirow[t]{2}{*}{ EMU } & 0.020 & & 0.029 & \\
\hline & $(0.020)$ & & $(0.021)$ & \\
\hline \multirow[t]{2}{*}{$E M U_{\text {old }}$} & $-0.046^{*}$ & & $-0.047^{*}$ & \\
\hline & $(0.024)$ & & $(0.026)$ & \\
\hline \multirow[t]{2}{*}{$E M U_{\text {new }}$} & 0.061 & & 0.072 & \\
\hline & $(0.047)$ & & $(0.046)$ & \\
\hline \multirow[t]{2}{*}{$E M U_{\text {oldnew }}$} & $0.056^{*}$ & & $0.064 * *$ & \\
\hline & $(0.029)$ & & $(0.029)$ & \\
\hline Exporter Year FE & YES & YES & YES & YES \\
\hline Importer Year FE & YES & YES & YES & YES \\
\hline Country-pair FE & YES & YES & YES & YES \\
\hline Observations & 33,126 & 33,126 & 30,925 & 30,925 \\
\hline$R^{2}$ & 0.734 & 0.734 & 0.732 & 0.732 \\
\hline
\end{tabular}

We further estimate disaggregated effects by focusing on the trade among the "old", "new" and between the "old" and "new" EMU member countries. Our results indicate heterogeneous effect in both "old" and 
"new" country groups. Consistent with previous literature (see Berthou and Fontagné, 2008; De Nardis et al., 2008; Baldwin et al., 2008), our results indicate a reduction in the export concentration of about 5 percent in the group of "old" EMU countries. In contrast, our results also suggest an increase in export concentration in the trade between "old" and "new" EMU countries. Lastly, the reported coefficient for the group of "new" EMU countries is positive but statistically insignificant in both periods.

The evidence of a fall in export concentration in the bilateral trade of the "old" EMU countries is intuitive. These countries have similar economic development and production techniques and are better-off diversifying production to avoid excessive competition. Since there are no restrictions to trade in the euro area, members' production techniques (innovations) and natural endowments play an important role in the concentration of trade in the euro area. Also, external trade relations with non-EMU members is another important factor in the structure of trade concentration in the eurozone. For the "old" EMU members their role in international trade flows drives their trade in the euro area which we find to be less concentrated. On the other hand, the "new" EMU members rely heavily on trade within the eurozone which potentially limits their number of tradable commodities and export destinations.

Finally, we estimate the euro's effect on export concentration using product level data. In Table 3, the HHI is computed at (HS) 2-digits level and is based on export data at 6-digit (HS) level.

Table 3. Estimate of Export Concentration (Industry Level)

\begin{tabular}{|c|c|c|c|c|}
\hline \multirow{2}{*}{$\begin{array}{c}\text { World (38) Sample } \\
\text { VARIABLES }\end{array}$} & \multicolumn{2}{|c|}{$1995-2011$} & \multicolumn{2}{|c|}{$1995-2011$} \\
\hline & Model [1] & Model [2] & Model [3] & Model [4] \\
\hline \multirow[t]{2}{*}{ FTA } & $-0.017 * * *$ & $-0.017 * * *$ & $-0.017 * * *$ & $-0.016 * * *$ \\
\hline & $(0.001)$ & $(0.001)$ & $(0.001)$ & $(0.001)$ \\
\hline \multirow[t]{2}{*}{ EU } & $-0.018 * * *$ & $-0.022 * * *$ & $-0.018 * * *$ & $-0.022 * * *$ \\
\hline & $(0.002)$ & $(0.002)$ & $(0.002)$ & $(0.002)$ \\
\hline \multirow[t]{2}{*}{ EMU } & -0.001 & & -0.001 & \\
\hline & $(0.001)$ & & $(0.001)$ & \\
\hline \multirow[t]{2}{*}{$E M U_{\text {old }}$} & & $-0.013 * * *$ & & $-0.014 * * *$ \\
\hline & & $(0.001)$ & & $(0.001)$ \\
\hline \multirow[t]{2}{*}{$E M U_{\text {new }}$} & & 0.006 & & 0.003 \\
\hline & & $(0.007)$ & & $(0.007)$ \\
\hline \multirow[t]{2}{*}{$E M U_{\text {oldnew }}$} & & $0.0132 * * *$ & & $0.0137 * * *$ \\
\hline & & $(0.002)$ & & $(0.002)$ \\
\hline Exporter Year FE & YES & YES & YES & YES \\
\hline Importer Year FE & YES & YES & YES & YES \\
\hline Industry Year FE & YES & YES & YES & YES \\
\hline Exporter Importer FE & YES & YES & NO & NO \\
\hline Exporter Importer Industry FE & NO & NO & YES & YES \\
\hline Observations & 408,319 & 408,319 & 407929 & 407929 \\
\hline$R^{2}$ & 0.731 & 0.733 & 0.738 & 0.74 \\
\hline
\end{tabular}


The results are consistent with our baseline findings in Table 2. Thus, we find industry-level evidence of a decrease in export concentration in trade among the "old" EMU members but an increase in export concentration in trade between "old" and "new" EMU members.

\section{Sensitivity Analysis}

As discussed in Rose (2017), a number of factors can bias the estimation of the euro's effect on trade. We test the sensitivity of our results by focusing on three of these factors that are likely to affect our results. The analysis is categorized under three subsections: (5.1) the number of countries under analysis; (5.2) the nature of countries included in the estimation; Related to this analysis, we also estimate whether there exists any evidence of trade diversion since a currency union can divert trade from high-cost producers (non-union member) to low-cost producers (union member) and vice versa; (5.3) the time span covered by the analysis.

\subsection{The Number of Countries Under Analysis}

Table 4 presents the results obtained by restricting the sample to the 28 EU countries for the same period as in Table 1.

We use this approach since there exists a number of large sample evidence in the literature. For easy comparison, we will refer to our main sample as the baseline sample and the sub-sample of 28 EU countries (used for the results in Table 3) as the EU sample. From Table 4, the estimated euro's effect on trade though positive is statistically insignificant as that reported in Table 1. Also, the euro's effect on trade for the "new" EMU members is positive and significant but of a slightly larger magnitude. We, however, find subtle changes in the estimate of trade between the "new" and "old" and among the "old" EMU countries. Thus, the results show a statistically significant (10 percent) negative effect on trade among the "old" EMU countries

Our results seem to contrast the argument that small observations used in estimating the euro's effect are likely to cause underestimation. Thus, our point estimate of the EMU dummy in both the baseline and EU sample falls in the range of those documented in Larch et al., (2019) which used a sample of 200 countries for the period 1948-2013. Other contributions which exploit larger sample of countries (Zymek et al., 2018 and Ciéslik et al., 2012) have concluded on a statistical insignificant euro's effect on trade.

\subsection{The Nature of Countries Included in the Estimation}

In this analysis, we only considered countries of relatively homogeneous economic size and development. For easy comparison, we focus on OECD countries. There are 30 OECD countries in the sample. Hence, estimating a model of only OECD countries motivate our quest in three ways: (i) it represents a further robustness check on the "size of the 
sample" argument; (ii) we are able to estimate the euro's effect assuming that the EMU is composed of only OECD- EMU countries; (iii) we only focus on countries with comparable economic size thus avoiding issues related to sample selection and matching.

Table 4. PPML- EU (28) Estimates

\begin{tabular}{|c|c|c|c|c|}
\hline \multicolumn{5}{|c|}{ EU (28) Sample Dependent Variable: Bilateral Exports } \\
\hline VARIABLES & Model [1] & Model [2] & Model [3] & Model [4] \\
\hline \multirow[t]{2}{*}{ InGDPeGDPm } & 0.398 & 0.425 & & \\
\hline & $(0.291)$ & $(0.288)$ & & \\
\hline \multirow[t]{2}{*}{ InEXe } & $0.156^{* *}$ & $0.157^{* *}$ & & \\
\hline & $(0.078)$ & $(0.078)$ & & \\
\hline \multirow[t]{2}{*}{ InEXm } & $0.124 * *$ & $0.126 * *$ & & \\
\hline & $(0.060)$ & (0.059) & & \\
\hline \multirow[t]{2}{*}{ FTA } & 0.002 & -0.014 & -0.086 & -0.053 \\
\hline & $(0.041)$ & $(0.037)$ & $(0.077)$ & $(0.077)$ \\
\hline \multirow[t]{2}{*}{ EU } & $0.236 * * *$ & $0.247^{* * *}$ & 0.119 & 0.103 \\
\hline & $(0.071)$ & $(0.070)$ & $(0.090)$ & $(0.088)$ \\
\hline \multirow[t]{2}{*}{ EMU } & $0.253 * * *$ & & 0.006 & \\
\hline & $(0.085)$ & & $(0.034)$ & \\
\hline \multirow[t]{2}{*}{$E M U_{\text {old }}$} & & $0.314 * * *$ & & $-0.098^{*}$ \\
\hline & & $(0.100)$ & & $(0.057)$ \\
\hline \multirow[t]{2}{*}{$E M U_{\text {new }}$} & & $0.383^{* *}$ & & $0.473 * * *$ \\
\hline & & $(0.161)$ & & $(0.131)$ \\
\hline \multirow[t]{2}{*}{$E M U_{\text {oldnew }}$} & & -0.043 & & $0.160 * * *$ \\
\hline & & $(0.223)$ & & $(0.061)$ \\
\hline Exporter Year FE & NO & NO & YES & YES \\
\hline Importer Year FE & NO & NO & YES & YES \\
\hline Country-pair FE & YES & YES & YES & YES \\
\hline Year FE & YES & YES & NO & NO \\
\hline Observations & 18,006 & 18,006 & 18,794 & 18,794 \\
\hline$R^{2}$ & 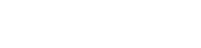 & . & 0.986 & 0.986 \\
\hline
\end{tabular}

We report in Table 5 results from the estimation of equation (2) which includes the trade diversion dummy. In Table 5, our results show a negative and statistically significant euro's effect on trade. However, the negative effect disappears when we add to the specification, the trade diversion dummy. The coefficient of the trade diversion dummy is positive and significant. This hypothetically indicates that if the euro is to be shared by OECD-EMU countries, then their trade with other non-OECD-EMU members is undoubtedly crucial. Importantly, in the specifications where we control for trade diversion (Model 2 using OECD 30 sample), our results are quite consistent with our baseline findings in Table 1. Using the OECD sample, we excluded the analysis of the disaggregated (country groups) effect because a few of the "new" EMU 
members were also OECD members (Slovakia in 2000, both Slovenia and Estonia in 2010).

Finally, the results of estimating equations (2) using the baseline sample are reported in the last two columns of table 5. While the results support our baseline findings, the statistically significant diversion effect disappears showing both positive and negative coefficients. Thus, collaborating existing results, there exists no evidence of trade diversion from non-EMU to EMU members despite the introduction of the euro. This finding is very much in line with that reported in Micco et al., (2003). The US, Japan, and more recently China, are important external markets for most EMU countries.

Table 5. PPML- OECD (30) Estimates

\begin{tabular}{|c|c|c|c|c|c|c|}
\hline \multicolumn{7}{|c|}{ Dependent Variable: Bilateral Exports } \\
\hline & \multicolumn{2}{|c|}{ EXCLUDE ZERO } & \multicolumn{2}{|c|}{ INCLUDE ZERO } & \multicolumn{2}{|c|}{ INCLUDE ZERO } \\
\hline & OECD (30) & & OECD (30) & & BASELINE & \\
\hline VARIABLES & Model [1] & Model [2] & Model [3] & Model [4] & Model [5] & Model [6] \\
\hline \multirow[t]{2}{*}{ FTA } & 0.005 & 0.012 & -0.023 & -0.014 & 0.066 & 0.067 \\
\hline & $(0.059)$ & $(0.060)$ & $(0.061)$ & $(0.061)$ & $(0.051)$ & $(0.051)$ \\
\hline \multirow[t]{2}{*}{ EU } & 0.097 & 0.104 & 0.070 & 0.078 & $0.138 * *$ & $0.114^{* *}$ \\
\hline & $(0.069)$ & $(0.069)$ & $(0.072)$ & $(0.072)$ & $(0.061)$ & $(0.058)$ \\
\hline \multirow[t]{2}{*}{ EMU } & $-0.162 * * *$ & 0.027 & $-0.135 * *$ & 0.109 & 0.013 & \\
\hline & $(0.061)$ & $(0.088)$ & $(0.062)$ & $(0.089)$ & $(0.114)$ & \\
\hline \multirow[t]{2}{*}{$E M U_{\text {old }}$} & & & & & & $-0.271^{*}$ \\
\hline & & & & & & $(0.157)$ \\
\hline \multirow[t]{2}{*}{$E M U_{\text {new }}$} & & & & & & 0.216 \\
\hline & & & & & & $(0.181)$ \\
\hline \multirow[t]{2}{*}{$E M U_{\text {oldnew }}$} & & & & & & -0.018 \\
\hline & & & & & & $(0.079)$ \\
\hline \multirow[t]{2}{*}{ DV } & & \multicolumn{2}{|c|}{$0.108 *$} & $0.140 * *$ & 0.024 & -0.111 \\
\hline & & \multicolumn{2}{|c|}{$(0.062)$} & $(0.063)$ & $(0.079)$ & $(0.087)$ \\
\hline Exporter Year FE & YES & YES & YES & YES & YES & YES \\
\hline Importer Year FE & YES & YES & YES & YES & YES & YES \\
\hline Country-pair FE & YES & YES & YES & YES & YES & YES \\
\hline Year FE & NO & NO & NO & NO & NO & NO \\
\hline Observations & 21,985 & 21,985 & 22,203 & 22,203 & 36,026 & 36,026 \\
\hline$R^{2}$ & & & & & 0.943 & 0.943 \\
\hline
\end{tabular}

***,**,* represent $1 \%, 5 \%$ and $10 \%$ significant level respectively, standard errors are in brackets.

Do the results from the OECD sample invalidate our previous findings? Looking at Larch et al., (2017), our answer is certainly "no". Using a sample of over 800,000 observations, they documented (elasticities) -0.203, -0.117- and -0.067-euro's effect on trade using the OECD sample in their data for the period 1948-2005, 1985-2005 and 1995-2005 respectively. There is not much difference in their results and those reported in Table 5. It is important to add that since Malta, Latvia, Lithuania and Cyprus were not 
yet members of the OECD ${ }^{11}$ in 2015, the estimated EMU coefficients in table 4 (OECD 30 sample) exclude these countries.

\subsection{The Time Span Covered by the Analysis}

As argued in Baldwin (2006), the institutional changes in Europe in 1992 can bias the estimation of the euro's effect if not properly controlled for in the empirical specification. One of these institutional changes was the removal of EU internal customs that led to the change in the recording system of trade flows in most EU countries. To avoid this problem, we re-estimate the euro's effect for the period 1993-2015. Table 6 presents the results using the Baseline, EU and OECD samples for the period 1993-2015. Clearly, the results in Table 6 are quite consistent with those presented in previous tables. More specifically, we correctly estimated the statistical insignificance of the euro's effect in [Model 1] and [Model 2] using the EU (28) and OECD (30) samples respectively. Moreover, EMU new is also correctly estimated.

Table 6. PPML- Basline, EU (28) and OECD (30) Estimates

\begin{tabular}{|c|c|c|c|c|c|c|}
\hline \multirow{2}{*}{$\begin{array}{l}\text { PERIOD: 1993-2015 } \\
\text { Dependent Variable: } X_{\mathrm{ijt}} \geq 0\end{array}$} & \multicolumn{2}{|l|}{ BASELINE } & \multicolumn{2}{|c|}{ EU (28) SAMPLE } & \multicolumn{2}{|c|}{ OECD (30) SAMPLE } \\
\hline & $\begin{array}{c}\text { Model } 1 \\
{[1]}\end{array}$ & $\begin{array}{c}\text { Model } 2 \\
{[2]}\end{array}$ & $\begin{array}{c}\text { Model } 1 \\
\text { [3] }\end{array}$ & $\begin{array}{c}\text { Model } 2 \\
{[4]}\end{array}$ & $\begin{array}{c}\text { Model } 1 \\
{[5]}\end{array}$ & $\begin{array}{c}\text { Model } 2 \\
{[6]}\end{array}$ \\
\hline FTA & $\begin{array}{r}0.033 \\
(0.053)\end{array}$ & $\begin{array}{l}0.040 \\
(0.053)\end{array}$ & $\begin{array}{l}-0.129 \\
(0.091)\end{array}$ & $\begin{array}{l}-0.091 \\
(0.091)\end{array}$ & $\begin{array}{l}-0.024 \\
(0.075)\end{array}$ & $\begin{array}{l}-0.014 \\
(0.076)\end{array}$ \\
\hline EU & $\begin{array}{l}0.088 \\
(0.073)\end{array}$ & $\begin{array}{l}0.044 \\
(0.070)\end{array}$ & $\begin{array}{l}0.054 \\
(0.125)\end{array}$ & $\begin{array}{l}0.014 \\
(0.120)\end{array}$ & $\begin{array}{l}0.069 \\
(0.098)\end{array}$ & $\begin{array}{l}0.071 \\
(0.099)\end{array}$ \\
\hline EMU & $\begin{array}{l}-0.158^{* *} \\
(0.074)\end{array}$ & & $\begin{array}{l}0.007 \\
(0.038)\end{array}$ & & $\begin{array}{l}-0.201 * * \\
(0.084)\end{array}$ & $\begin{array}{l}0.071 \\
(0.086)\end{array}$ \\
\hline$E M U_{\text {old }}$ & & $\begin{array}{l}-0.226 * * * \\
(0.086)\end{array}$ & & $\begin{array}{l}-0.131^{*} \\
(0.067)\end{array}$ & & \\
\hline$E M U_{n e w}$ & & $\begin{array}{l}0.389 * * \\
(0.156)\end{array}$ & & $\begin{array}{l}0.475 * * * \\
(0.130)\end{array}$ & & \\
\hline$E M U_{\text {oldnew }}$ & & $\begin{array}{l}0.102 \\
(0.070)\end{array}$ & & $\begin{array}{l}0.167 * * * \\
(0.060)\end{array}$ & & \\
\hline DV & & & & & & $\begin{array}{l}0.161 * * \\
(0.076)\end{array}$ \\
\hline Exporter Year & YES & YES & YES & YES & YES & YES \\
\hline Importer Year & YES & YES & YES & YES & YES & YES \\
\hline Country-pair FE & YES & YES & YES & YES & YES & YES \\
\hline Observations & 31,754 & 31,754 & 16,964 & 16,964 & 19,554 & 19,554 \\
\hline$R^{2}$ & 0.949 & 0.949 & 0.986 & 0.986 & 0.944 & 0.944 \\
\hline
\end{tabular}

Finally, as done in both Larch et al., (2019) and Zymek et al., (2018), we estimate our specification using a dataset similar to that in Glick and Rose

11 Latvia and Lithuania obtained OECD membership in 2016 and 2018 respectively. 
(2016). The limitation of using these data is that since the sample ends in 2013, estimates of the EMU effect are likely to exclude the effect of Latvia and Lithuania. That notwithstanding, the estimates as shown in Table A.3 (see appendix) indicate the statistical insignificance of the euro's effect on bilateral exports, but a relatively large $E M U_{\text {new }}$ effect as reported in the baseline results. Moreover, as done in Table 6, restricting the sample to the period 1993-2015, the results are again consistent with our baseline results. Using a Panel Fixed Effect (FE) estimator, we again found a larger euro's effect on the "new" EMU members. Furthermore, the evidence of no trade diversion is also found to be consistent. These results are not reported but are available upon request.

It is important to state that most of the earlier contributions to the literature (Micco et al., 2003; Berger and Nitsch, 2008; Flam and Norstrom, 2003 among others) prior to (SST, 2006) employed the use of the panel fixed effect estimator. While their results were based on limited post-EMU observations, the Panel FE estimator they used is based on the log-linearization of the gravity model, which is sometimes a challenge, especially when there are a lot of zeros or missing bilateral trade flows in the sample. For this reason, this estimator only works on the necessary condition that $X_{\mathrm{ijt}}>0$. Moreover, as argued in SST, the FE estimator tends to be unbiased, but inconsistent in the presence of heteroscedasticity.

\section{Conclusions}

In this paper, we set out to study the euro's effect on trade for both the "old" and "new" EMU members for the period 1988-2015. We estimated a theory-consistent gravity model controlling for both time and country heterogeneity effects. We used the PPML estimator, and we conducted a number of robustness checks to test the sensitivity of our results. We found that the euro's effect is statistically insignificant on bilateral exports. Moreover, disaggregating the total euro's effect to that of "new" and "old" EMU members, we found a statistically significant euro's effect of between 42-60 percent of bilateral export on the "new" EMU members. For the "old" EMU members, the euro's effect is for most estimates negative and statistically insignificant.

Our results on the "new" EMU countries contrast with the conclusions by Zymek et al., (2018) and Cieślik et al., (2012, 2014). However, our baseline findings on the aggregate euro's effect on trade are consistent with (Zymek et al., 2018; Cieślik et al., 2012, 2014; Larch et al., 2019). We then add to the list of contributions that contrast the results in Glick and Rose (2016). Consistent with the findings in Micco et al., (2003), we found no evidence of trade diversion between EMU and non-EMU countries.

We also extended the analysis to provide evidence of the impact of the euro on export concentration using the HHI. Our results indicate a reduction in bilateral export concentration in the "old" EMU countries. This finding is consistent with the literature focusing on the "old" EMU countries. We find no evidence of bilateral export concentration at the 
aggregate EMU level. Similar result is found in the trade among the "new" EMU countries. What we find puzzling is the evidence of an increase in bilateral export concentration of trade between the "new" and "old" EMU countries. As a result, more inquiry on the subject is required.

Our study suggests that the adoption of the euro has been beneficial for trade among "new" EMU countries. However, further analysis reveals an increase in export concentration in trade among "new" EMU countries. These findings are key to the recent policy debate about the trade relevance of the euro adoption for new entrants. In terms of trade, much of what is expected to happen to new entrants after the adoption of the euro depends on the extent of factors such as trade openness, factor mobility, capital market development and similarities of institutions and other macroeconomic factors between the new entrants and other EMU members. Hence, the euro is likely to be beneficial to new entrants if the above factors are well adhered to. Actually, these are important factors that ensure economic re-balancing in a monetary union given any shock.

In order to extend our conclusions to new EMU entrants, some caution should be taken. Thus, as far as other CEECs in transit to the EU are concerned, there is the need to converge and synchronize their economies to the EMU average. For the "new" EMU members, the Exchange Rate Mechanism (ERM II) was a good pathway to the convergence of their economies to the "old" EMU members. Currently, countries like Poland, Hungary, Czech Republic, Croatia among others, are yet to fully exploit this convergence avenue. Hence, the large positive euro's effect on trade for the "new" EMU members should not be over-stretched in the case of other CEECs in transit to the EMU. Thus, the benefit of increasing trade should be assessed against the cost of an increase in bilateral export concentration.

\section{References}

Anderson, J.E., 1979. A Theoretical Foundation for the Gravity Equation. American Economic Review 69, 106-116.

Anderson, J.E., Van Wincoop, E., 2001. Borders, Trade and Welfare. NBER WP 8515, October.

Baldwin, R.E., 2006. The Euro's Trade Effects. ECB Working Paper, No. 594.

Baldwin, R.E., Taglioni, D., 2007. Trade Effects of the Euro: A Comparison of Estimators. Journal of Economic Integration 22, 780-818.

Baldwin R., Di Nino, V., Fontagne, L., De Santis, R.A. Taglioni, D., 2008. Study on the Impact of the Euro on Trade and Foreign Direct Investment. European Economy Economic Papers no. 321, May. 
Barr, D., Breedon, F., Miles, D., 2003. Life on the Outside: Economic conditions and prospects outside Euroland. Economic Policy 18, 573-613.

Belke, A., Spies, J., 2008. Enlarging the EMU to the East: What Effects on trade? Empirica 35, 369-389.

Berger, H., Nitsch, V., 2008. Zooming Out: The Trade Effect of the Euro in Historical Perspective. Journal of International Money and Finance 27, 1244-1260.

Bergstrand, J.H., 1990. The Heckscher-Ohlin-Samuelson Model, the Linder Hypothesis and the Determinants of Bilateral Intra-industry Trade. The Economic Journal 100(403), 1216-1229.

Berthou, A., Fontagne, L., 2008. The euro and the intensive and extensive margins of trade: Evidence from French firm level data. CEPII Working Paper 2008-06, May.

Cieślik, A., Michałek, J.J. and Mycielski, J., 2012. Measuring the Trade Effects of the euro in Central and Eastern Europe. The Journal of International Trade and Economic Development 21, 25-49.

Cieślik, A., Michałek, J.J., Mycielski, J., 2014. Trade Effects of the Euro Adoption by the EU New Member States. Bank i Kredyt 45, 331-348.

De Nardis, S., Pappalardo, C., Vicarelli, C., 2008. The Euro Adoption's Impact on Extensive and Intensive Margins of Trade: The Italian Case. Istituto di Studi e Analisi Economica Working Paper No. 101.

Egger, P., Larch, M., 2008. Interdependent Preferential Trade Agreement Memberships: An Empirical Analysis. Journal of International Economics 76, 384-399.

Feenstra, R.C., 2004. Advanced International Trade: Theory and Evidence. Princeton University Press, Princeton, NJ.

Flam, H., Nordstrom, H., 2003. Trade Volume Effects of the Euro: Aggregate and Sector Estimates. Institute for International Economic Studies, mimeo.

Fontagné, L., Mayer, T., Ottaviano, G.I., 2009. Of Mmarkets, Products and Prices: The Effects of the Euro on European fFrms. Intereconomics 44, 149-158.

Glick, R., Rose, A. K., 2002. Does a Currency Union Affect Trade? The Time-series Evidence. European Economic Review 46, 1125-1151. 
Glick, R., Rose, A.K., 2016. Currency Unions and Trade: A post-EMU reassessment. European Economic Review 87, 78-91.

Head, K., Thierry M., 2014. Gravity Equations: Workhorse, Toolkit, and Cookbook. Chapter 3 in Gopinath, G., E. Helpman and K. Rogoff (eds), vol. 4 of the Handbook of International Economics (Elsevier, Amsterdam), pp. 131-195.

Larch, M., Wanner, J., Yotov, Y.V., Zylkin, T., 2019. Currency Unions and Trade: A PPML Re-assessment with High-dimensional Fixed Effects. Oxford Bulletin of Economics and Statistics 81, 487-510.

Maliszewska, M.A., 2004. New Member States Trading Potential Following EMU Accession: A gravity approach, Studies and Analyses, 286, CASE - Center for Social and Economic Research.

Micco, A., Stein, E., Ordoñez, G., 2003. The Currency Union Effect on Trade: Early Evidence from EMU. Economic Policy 18, 315-356.

Mika, A., Zymek, R., 2018. Friends without Benefits? New EMU members and the "Euro Effect" on Trade. Journal of International Money and Finance 83, 75-92.

Persson, T., 2001. Currency Unions and Trade: How Large is the Treatment Effect? Economic Policy 16, 434-448.

Rose, A.K., 2000. One Money, One Market: The Effect of Common Currencies on Trade. Economic Policy 15, 8-45.

Rose, A.K., 2017. Why do Estimates of the EMU Effect on Trade Vary So Much? Open Economies Review 28, 1-18.

Rose, A.K., Van Wincoop, E., 2001. National Money as a Barrier to International Trade: The Real Case for Currency Union. American Economic Review 91, 386-390.

Silva, J.S., Tenreyro, S., 2006. The Log of Gravity. The Review of Economics and Statistics 88, 641-658.

Tenreyro, S., 2001. On the Causes and Consequences of Currency Unions. Harvard University, unpublished. 


\section{Appendix}

Table A.1. Summary Statistics

\begin{tabular}{|c|c|c|c|c|c|}
\hline Variables & & Mean & Std. Dev. & Min & Max \\
\hline \multirow[t]{3}{*}{ In(Bil.Expts ) } & overall & 19.001 & 3.046707 & 2.108425 & $27.58471 \mathrm{~N}=35581$ \\
\hline & between & & 2.880675 & 7.108208 & $26.04075 n=1406$ \\
\hline & within & & 1.010617 & 7.661089 & $35.51792 \mathrm{~T}-\mathrm{bar}=25.3$ \\
\hline \multicolumn{6}{|l|}{ In(GDPem) } \\
\hline & overall & 51.9969 & 2.72025 & 43.60304 & $60.55304 \mathrm{~N}=36366$ \\
\hline & between & & 2.530248 & 45.38641 & $59.11085 n=1406$ \\
\hline & within & & 0.9953118 & 49.06829 & 55.0281T-bar $=25.9$ \\
\hline \multirow[t]{3}{*}{$\ln (E X)$} & overall & 0.6911508 & 1.733699 & -7.094085 & $5.657703 \mathrm{~N}=37777$ \\
\hline & between & & 1.595571 & -1.059861 & $5.084888 n=1406$ \\
\hline & within & & 0.6503173 & -5.343073 & 2.683069T-bar $=26.9$ \\
\hline \multirow[t]{3}{*}{ FTA } & overall & 0.2575696 & 0.4373012 & 0 & $1 N=39368$ \\
\hline & between & & 0.307304 & 0 & $1 n=1406$ \\
\hline & within & & 0.3112256 & -0.7067161 & $1.221855 \mathrm{~T}=28$ \\
\hline \multirow[t]{3}{*}{ EU } & overall & 0.2808626 & 0.4494262 & 0 & $1 N=39368$ \\
\hline & between & & 0.3233576 & 0 & $1 n=1406$ \\
\hline & within & & 0.3122428 & -0.4691374 & $1.17372 T=28$ \\
\hline \multirow[t]{3}{*}{ EMU } & overall & 0.0843833 & 0.2779653 & 0 & $1 N=39368$ \\
\hline & between & & 0.1826132 & 0 & $0.6071429 n=1406$ \\
\hline & within & & 0.2096187 & -0.5227596 & $1.048669 \mathrm{~T}=28$ \\
\hline \multirow[t]{3}{*}{ DV } & overall & 0.2335907 & 0.4231201 & 0 & $1 N=39368$ \\
\hline & between & & 0.269745 & 0 & $0.6071429 n=1406$ \\
\hline & within & & 0.3260647 & -0.3735521 & $1.197876 \mathrm{~T}=28$ \\
\hline
\end{tabular}


Figure A1.1. Euro Area Trade in Goods (in billions of US)

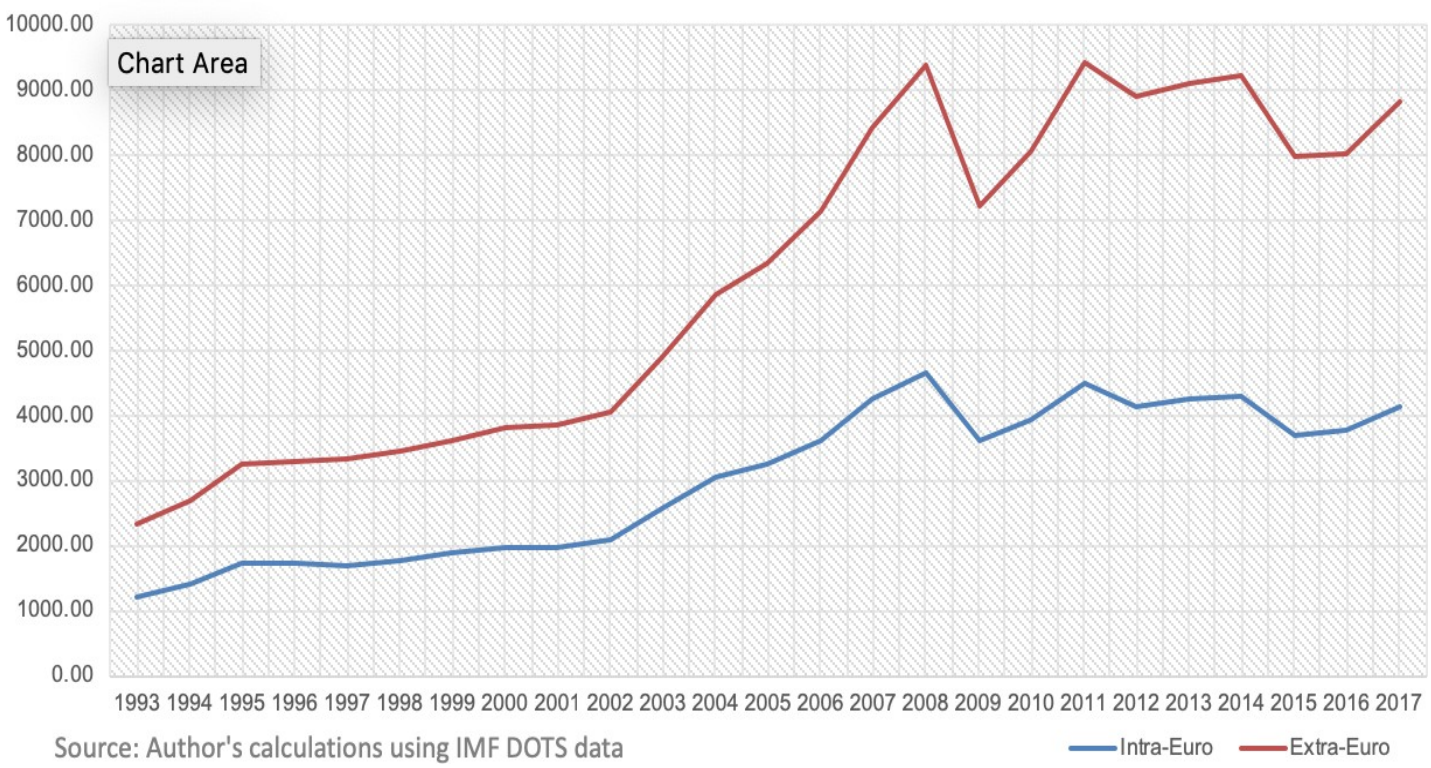

Figure A1.2. Percentage Share of Intra-Euro Goods Trade- New EMU members

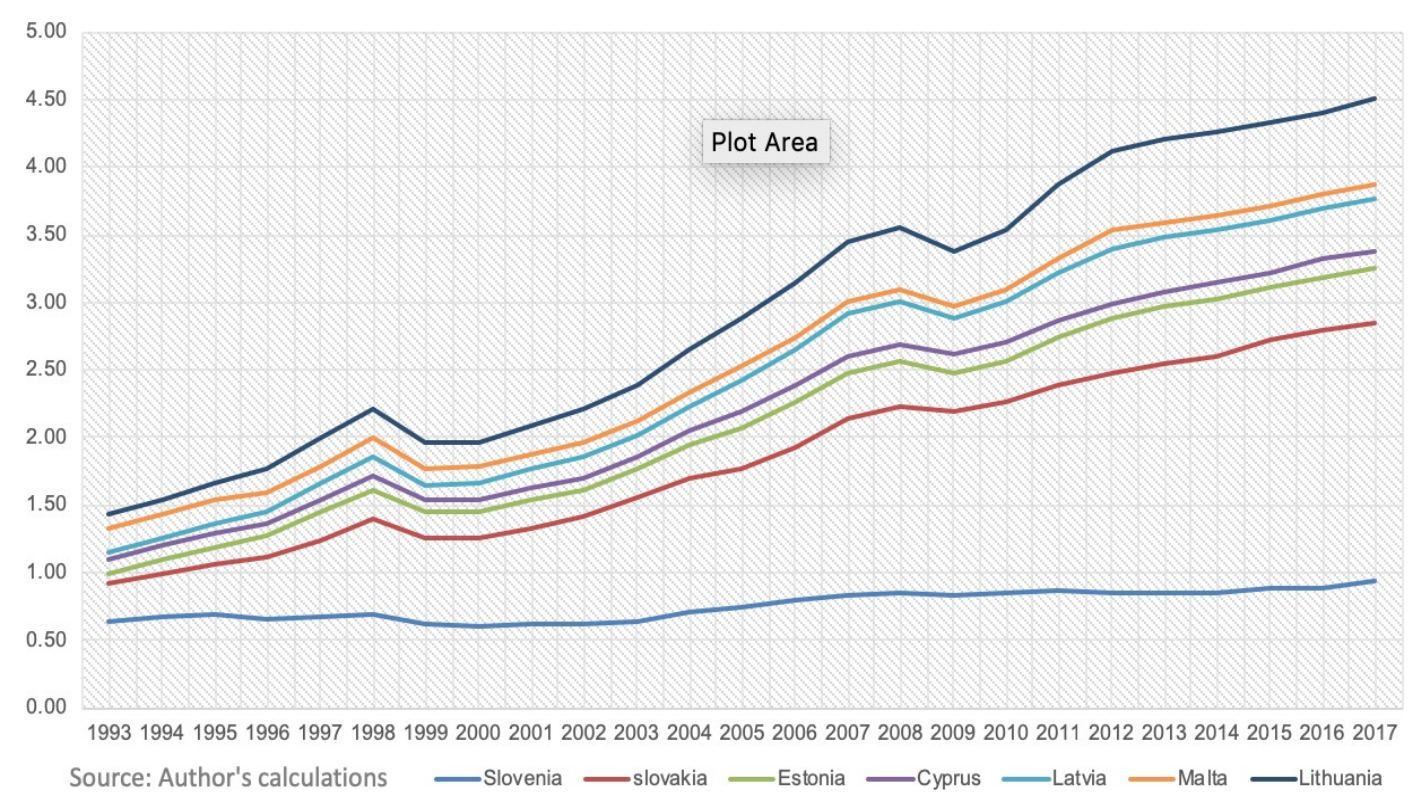


Figure A.2. Bar Graph of the Euro's Effect on Trade

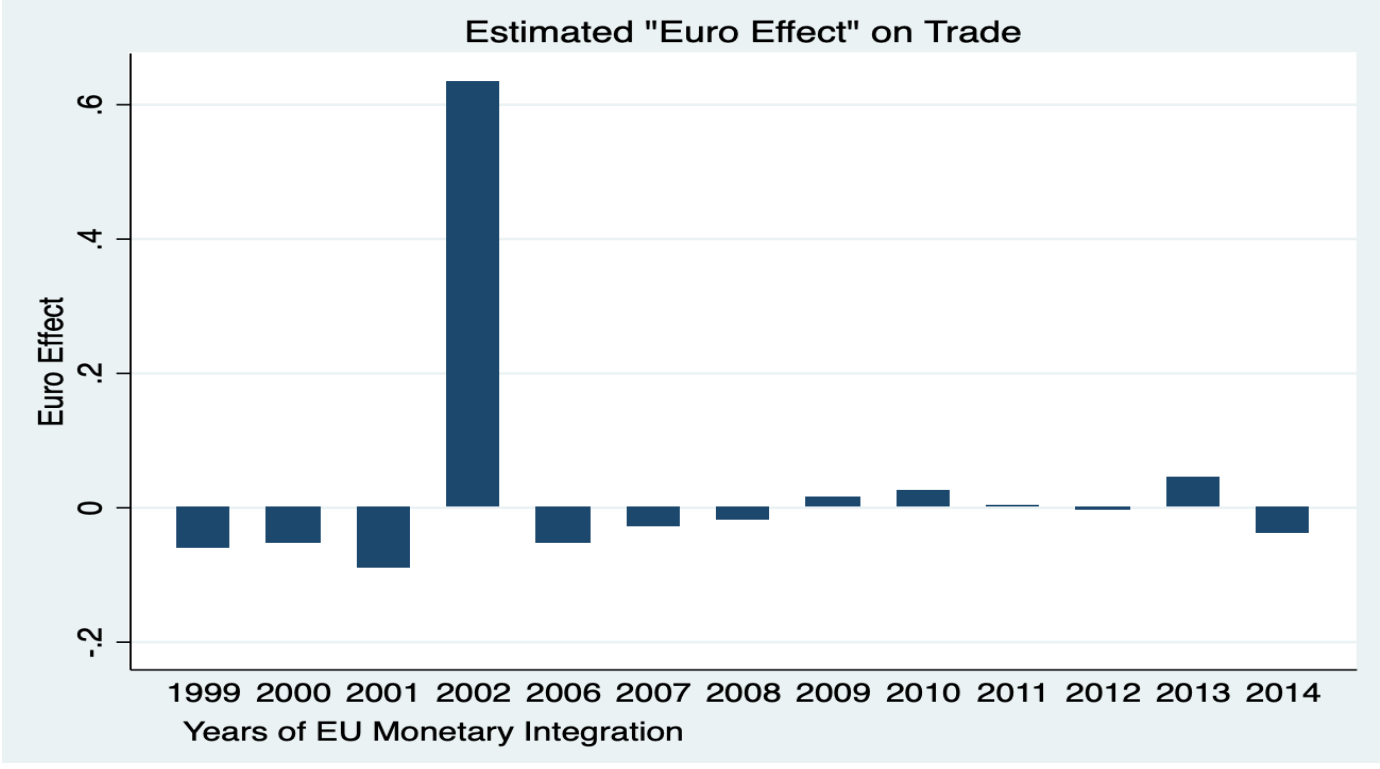

Table A.2. Euro's Effect on Trade

\begin{tabular}{|c|c|c|c|c|c|c|c|}
\hline Year & 1999 & & 2000 & 2001 & 2002 & 2006 & 2007 \\
\hline Euro effect & $\begin{array}{c}-0.060 \\
(0.047)\end{array}$ & & $\begin{array}{l}-0.054 \\
(0.046)\end{array}$ & $\begin{array}{l}-0.0907^{* *} \\
(0.045)\end{array}$ & $\begin{array}{l}0.635^{* * *} \\
(0.217)\end{array}$ & $\begin{array}{l}-0.054 \\
(0.040)\end{array}$ & $\begin{array}{l}-0.029 \\
(0.038)\end{array}$ \\
\hline Year & 2008 & 2009 & 2010 & 2011 & 2012 & 2013 & 2014 \\
\hline Euro effec 1 & $\begin{array}{l}-0.020 \\
(0.040)\end{array}$ & $\begin{array}{l}0.015 \\
(0.041)\end{array}$ & $\begin{array}{l}0.025 \\
(0.039)\end{array}$ & $\begin{array}{l}0.003 \\
(0.043)\end{array}$ & $\begin{array}{l}-0.005 \\
(0.041)\end{array}$ & $\begin{array}{l}0.045 \\
(0.063)\end{array}$ & $\begin{array}{c}-0.039 \\
(0.045)\end{array}$ \\
\hline
\end{tabular}

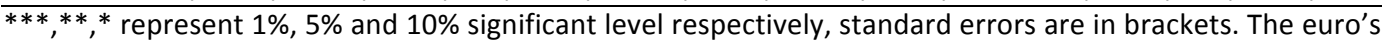
effect for year 2003, 2004, 2005 and 2015 are not reported because of non-convergence

Table A.3. PPML Estimates- Larger Sample

\begin{tabular}{|c|c|c|c|c|}
\hline \multicolumn{5}{|c|}{ ROSE-LIKE Sample (206) Dependent Variable: Bilateral Export Trade } \\
\hline \multirow[b]{2}{*}{ VARIABLES } & 1988-2013 & \multicolumn{3}{|c|}{ 1993-2013 } \\
\hline & Model [1] & Model [2] & Model [3] & Model [4] \\
\hline \multirow[t]{2}{*}{ RTA } & $-0.100 * * *$ & $-0.100 * * *$ & $-0.079 * * *$ & $-0.079 * * *$ \\
\hline & $(0.012)$ & $(0.012)$ & $(0.012)$ & $(0.012)$ \\
\hline \multirow[t]{2}{*}{ EU } & $0.337 * * *$ & $0.336 * * *$ & $0.274 * * *$ & $0.272 * * *$ \\
\hline & $(0.015)$ & $(0.015)$ & $(0.016)$ & $(0.016)$ \\
\hline \multirow[t]{2}{*}{ EMU } & -0.002 & & 0.010 & \\
\hline & $(0.010)$ & & $(0.011)$ & \\
\hline \multirow[t]{2}{*}{$E M U_{\text {old }}$} & -0.005 & & & 0.005 \\
\hline & $(0.010)$ & & & $(0.012)$ \\
\hline \multirow[t]{2}{*}{$E M U_{\text {new }}$} & $0.365^{* * *}$ & & & $0.371 * * *$ \\
\hline & $(0.083)$ & & & $(0.082)$ \\
\hline \multirow[t]{2}{*}{ EM Uoldnew } & 0.022 & & & 0.036 \\
\hline & $(0.026)$ & & & $(0.026)$ \\
\hline Exporter Year FE & YES & YES & YES & YES \\
\hline Importer Year FE & YES & YES & YES & YES \\
\hline Country-pair FE & YES & YES & YES & YES \\
\hline Observations & 526,360 & 526,360 & 454,945 & 454,945 \\
\hline$R^{2}$ & 0.993 & 0.993 & 0.994 & 0.994 \\
\hline
\end{tabular}


Table A.4. Industry Classification

\begin{tabular}{|c|c|c|}
\hline INDUSTRIES & SECTIONS & 2-DIGIT \\
\hline Live Animals and Animal Products & 1 & 01 to 05 \\
\hline Vegetable Products & 2 & 06 to 14 \\
\hline Animal or Vegetable Fat and oil and waxes & 3 & 15 \\
\hline Prepare foodstuffs, tobacco, beverages and Vinegar & 4 & 16 to 24 \\
\hline Mineral Products & 5 & 25 to 27 \\
\hline Products of chemical and allied industries & 6 & 28 to 38 \\
\hline Plastics and Rubber products & 7 & 39 to 40 \\
\hline Raw hides, leather, animal gut and silk-worm gut & 8 & 41 to 43 \\
\hline Wood, charcoal, basketware and wickerwork & 9 & 44 to 46 \\
\hline $\begin{array}{l}\text { Pulp of wood, other fibrous cellulosic material and } \\
\text { paperboard }\end{array}$ & 10 & 47 to 49 \\
\hline Textiles and Textile articles & 11 & 50 to 63 \\
\hline $\begin{array}{l}\text { Footwear, prepared feathers, artificial flowers and art. } \\
\text { human hair }\end{array}$ & 12 & 64 to 67 \\
\hline $\begin{array}{l}\text { Stone, plaster, cement and ceramic product, glass and } \\
\text { glassware }\end{array}$ & 13 & 68 to 70 \\
\hline Natural or pearls, precious stones and metals, jewellery & 14 & 71 \\
\hline $\begin{array}{l}\text { Vehicles, aircraft, vessels and associated transport } \\
\text { equipment }\end{array}$ & 17 & 86 to 89 \\
\hline $\begin{array}{l}\text { Optical, musical and medical instruments, clocks and } \\
\text { watches }\end{array}$ & 18 & 90 to 92 \\
\hline Arms and Ammunition & 19 & 93 \\
\hline Miscellaneous manufactured articles & 20 & 94 to 96 \\
\hline Works of art, collectors' pieces and antiques & 21 & 97 to 99 \\
\hline
\end{tabular}

